\title{
REAKSI PASAR TERHADAP PERISTIWA PEMILIHAN PRESIDEN TAHUN 2019 DI BURSA EFEK INDONESIA
}

\author{
Putu Agus Yudiawan 1 \\ Nyoman Abundanti ${ }^{2}$
${ }^{1,2}$ Fakultas Ekonomi dan Bisnis Universitas Udayana (Unud), Bali, Indonesia email: agusyudiawan4@gmail.com

\begin{abstract}
ABSTRAK
Tujuan penelitian ini adalah untuk mengetahui reaksi pasar terhadap peristiwa pemilihan presiden di Indonesia tahun 2019 yang diteliti menggunakan variabel abnormal return dan trading volume activity. Penelitian ini menggunakan pendekatan event study dengan 11 hari event window. Sampel penelitian berdasarkan purposive sampling sebanyak 63 perusahaan yang tergabung dalam Indeks IDX80. Dari hasil uji normalitas diketahui data tidak berdistribusi normal, maka metode uji hipotesis yang digunakan adalah Wilcoxon Signed Rank Test. Hasil dari penelitian ini menunjukkan (1) Tidak terdapat reaksi pasar yang signifikan dilihat dari rata-rata abnormal return sebelum dan sesudah peristiwa pemilihan. (2) Terdapat reaksi pasar yang signifikan dilihat dari rata-rata trading volume activity sebelum dan sesudah peristiwa pemilihan.

Kata Kunci: studi peristiwa, pemilihan presiden, abnormal return, trading volume activity.
\end{abstract}

\begin{abstract}
The purpose of this study was to determine the market reaction to the events of the presidential election in Indonesia in 2019 which was examined using the variable abnormal return and trading volume activity. This study uses an event study approach with an 11 day event window. The research sample was based on purposive sampling of 63 companies incorporated in the IDX80 Index. From the results of the normality test it is known that the data is not normally distributed, then the hypothesis test method used is the Wilcoxon Signed Rank Test. The results of this study indicate (1) There is no significant market reaction seen from the average abnormal return before and after the election event. (2) There is a significant market reaction as seen from the average trading volume activity before and after the election event.

Keywords: event study, presidential election, abnormal return, trading volume activity.
\end{abstract}




\section{PENDAHULUAN}

Pasar modal dapat diartikan sebagai pasar di mana para pelaku memperjualbelikan sekuritas baik itu saham maupun obligasi yang memiliki jangka waktu lebih dari satu tahun. Pengguna dari pasar modal adalah investor individu, pemerintah, maupun organisasi yang berorientasi pada laba dan non laba. Secara fisik di Indonesia jual-beli sekuritas atau efek dilakukan di Bursa Efek Indonesia (Jakarta Stock Exchange). Di berbagai negara, peran pasar modal sangatlah penting. Pasar modal berperan sebagai lembaga intermediasi yang menghubungkan investor dengan perusahaan terkait alternatif pendanaan (Diniar \& Kiryanto, 2016). Melalui pasar modal, dana yang dipercayakan oleh investor dapat dimanfaatkan secara produktif oleh perusahaan. Sebagai timbal balik kepada investor yakni dengan kenaikan nilai perusahaan yang tercermin dalam harga saham dan pembagian dividen.

Sebagai instrumen investasi dan alternatif pendanaan, pasar modal tidak terlepas dari pengaruh lingkungan ekonomi dan non ekonomi. Lingkungan ekonomi terbagi menjadi lingkungan ekonomi mikro dan makro (Altin, 2015). Lingkungan ekonomi mikro diantaranya corporate action dan lingkungan ekonomi makro seperti inflasi dan volatilitas nilai tukar turut berpengaruh terhadap harga dan volume perdagangan saham. Pengaruh dari lingkungan non ekonomi tidak kalah penting, lingkungan ini memiliki pengaruh yang menyeluruh dan selalu mengundang respon dari pelaku pasar (Chien et al., 2014), diantaranya pemilihan presiden, kerusuhan, peperangan, berbagai gejolak politik dan bencana alam (Santoso \& Sri Artini, 2015).

Informasi dibutuhkan untuk menggerakkan harga sekuritas di pasar modal, karena informasi pada hakekatnya menyajikan gambaran masa lalu, saat ini maupun keadaan di masa yang akan datang (Hoe \& Nippani, 2017). Dewasa ini, kemajuan teknologi yang sangat pesat menyebabkan informasi semakin cepat menyebar di masyarakat (Khan et al., 2017). Menurut Brigham dan Houston (2007:460) informasi yang dipublikasikan akan menjadi sinyal bagi pelaku pasar dalam pengambilan keputusan investasi. Apabila pasar bereaksi dengan cepat dan akurat dalam mencapai harga keseimbangan baru atas informasi dari suatu peristiwa maka pasar dikatakan efisien (Jogiyanto, 2016:605). Menurut Fama (1970) untuk menguji reaksi pasar atas peristiwa yang informasinya dipublikasikan dapat menggunakan pendekatan studi peristiwa (event study).

Reaksi pasar ditunjukkan dengan adanya perubahan harga sekuritas. Reaksi ini dapat diukur dengan abnormal return yang merupakan selisih antara return sesungguhnya terjadi dengan return ekspektasian (Kabiru et al., 2015). Apabila suatu peristiwa mengandung informasi maka akan memberikan abnormal return kepada pasar. Selain menggunakan abnormal return, pengujian terhadap efisiensi pasar dapat diukur dengan trading volume activity (Imelda et al., 2015). Trading volume activity digunakan oleh analis teknikal untuk mengukur besarnya likuditas perdagangan saham. Terjadinya abnormal return dan trading volume activity mengindikasikan informasi yang dipublikasikan direspon oleh investor dan mengakibatkan perubahan harga sekuritas.

Secara teoritis ketidakpastian politik akan berpengaruh terhadap supply dan demand akan sekuritas di pasar modal (Husnan, 2003:9). Peristiwa politik seperti 
pemilihan presiden tergolong ke dalam peristiwa kluster atau jarang terjadi (Tandelilin, 2010:567) yang memungkinkan investor belum mengetahui kandungan informasi apakah berdampak baik atau buruk sehingga memengaruhi keputusan investasi (Jiun, 2018). Hubungan antara keputusan investasi pelaku pasar dengan peristiwa pemilihan presiden bergantung pada konsep risiko politik yang didefinisikan sebagai perubahan yang tidak menguntungkan sehingga memengaruhi nilai investasi (Savita \& Ramesh, 2015).

Pemilihan presiden di Indonesia tahun 2019 sangat berbeda dengan pemilihan presiden yang pernah dilakukan di tahun 2014. Perbedaan mendasar pemilihan presiden tanggal 17 April 2019 adalah masyarakat memilih secara serentak calon anggota legislatif, yaitu anggota DPRD Kabupaten atau Kota, DPRD Provinsi, DPR RI dan DPD serta untuk eksekutif, yaitu calon presiden dan wakil presiden. Terkait jumlah partai politik pengusung calon presiden dan wakil presiden tahun 2019, karena penyelenggaraannya serentak maka disepakati menggunakan presidential threshold yang berasal dari hasil pemilihan legislatif tahun 2014. Peristiwa pemilihan presiden tersebut akan berakibat pada perubahan harga saham yang berfluktuasi. Perubahan harga saham tersebut dapat dilihat pada gambar berikut.

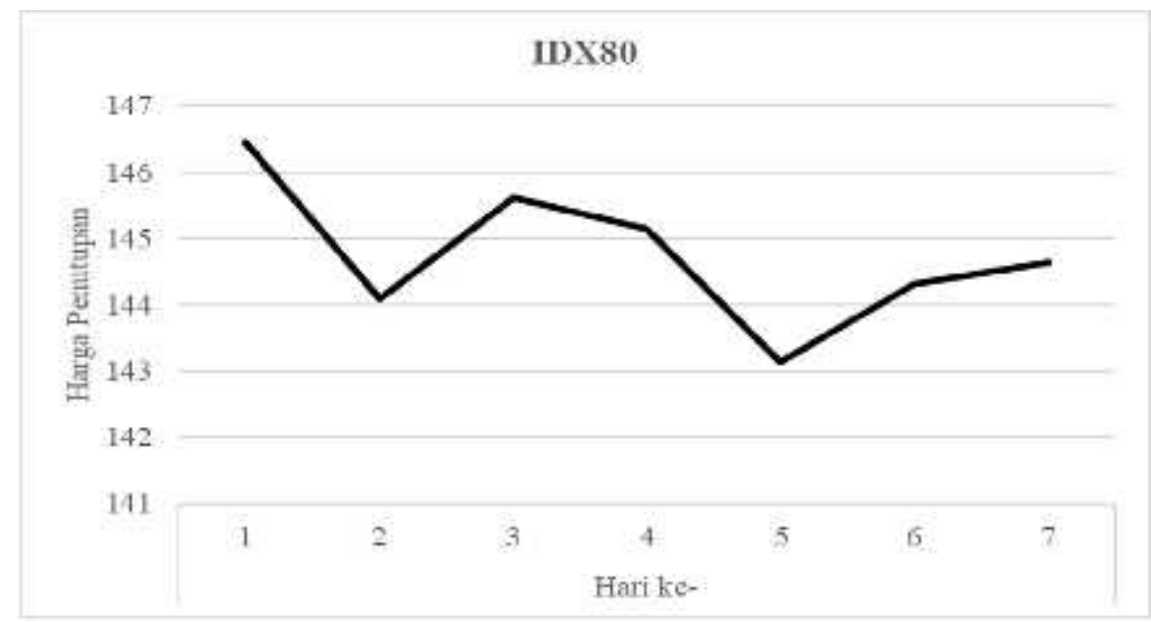

Gambar 1. Perubahan Harga Saham Indeks IDX80

Sumber: www.idx.co.id, 2019

Sehari setelah pemilihan presiden tahun 2019, rata-rata harga saham yang tergabung dalam Indeks IDX80 ditutup menguat sebesar 0,7 persen ke level 146,451. Tetapi, di hari kedua Indeks ini tidak melanjutkan penguatannya melainkan melemah cukup signifikan ke level 144,092. Secara empiris peristiwa politik lebih berpengaruh dalam jangka pendek dan berkurang dalam jangka panjang (Koulakiotis et al., 2016), dan untuk membuktikan pengaruh dari peristiwa pemilihan presiden tahun 2019 secara kuantitatif masih perlu dilakukan suatu kajian lebih lanjut.

Penelitian terdahulu tentang peristiwa pemilihan presiden menghasilkan beberapa temuan. Wong dan Hooy (2016) meneliti perbedaan CAAR bank di Indonesia, Malaysia dan Thailand di mana mendapatkan hasil bahwa selama periode pemilihan CAAR bank positif signifikan. Kusumayanti dan Suarjaya 
(2018) meneliti abnormal return pada peristiwa pengumuman kemenangan Donald Trump dan mendapatkan hasil bahwa peristiwa pengumuman kemenangan tersebut menimbulkan reaksi pasar. Hasil penelitian dari Osuala et $a l$., (2018) yang meneliti reaksi pasar terhadap pemilihan presiden di Nigeria, mendapatkan hasil negatif signifikan. Kemudian hasil penelitian dari Khim, Liew dan Rowland (2016) yakni 40 persen pasar saham bereaksi positif sebelum pemilihan sedangkan 60 persen bereaksi positif setelah pemilihan. Menurut penelitian yang dilakukan oleh Gatumo (2017) menyimpulkan bahwa pemilihan umum di Kenya memiliki efek positif signifikan pada Indeks NSE. Penelitian dari Diniar dan Kiryanto (2016) juga mendapatkan hasil yang sama, yakni pemilihan presiden tahun 2014 di Indonesia memberikan perubahan abnormal return dan trading volume activity yang signifikan. Serupa dengan penelitian sebelumnya di mana Sajid Nasir et al., (2014) menemukan bahwa peristiwa politik berdampak positif signifikan terhadap pasar saham.

Hasil penelitian berikut bertolak belakang dengan hasil penelitian sebelumnya, di mana Mahaputra dan Purbawangsa (2015) meneliti reaksi pasar terhadap peristiwa pemilihan legislatif tahun 2014 di Indonesia dan mendapatkan hasil yakni tidak terdapat perbedaan abnormal return. Kurniawati dan Herlambang (2015) mendapatkan hasil bahwa tidak ada perbedaan AAR dan TVA yang signifikan pada Jakarta Islamic Index sebelum dan sesudah pengumuman pemilihan presiden di Indonesia tahun 2014. Menurut penelitian yang dilakukan oleh Oka Sudewa P. dan Ratna Sari (2015) mendapatkan hasil bahwa tidak adanya reaksi pasar pada saat pelaksanaan pemilihan presiden tahun 2014 serta tidak terdapat perbedaan average abnormal return sebelum dan sesudah pemilihan presiden tahun 2014 pada Indeks LQ45. Katti (2018) juga mendapatkan hasil bahwa tidak ada perbedaan AAR (Average Abnormal Return) sebelum dan sesudah peristiwa politik di Indonesia. Hal ini menunjukkan prediksi dan informasi yang diterima oleh pelaku pasar relatif sama. Penelitian yang dilakukan oleh Obradovic dan Tomic (2017) menunjukkan bahwa tidak terdapat perbedaan CAR (Cumulative Abnormal Return) untuk 85 sampel perusahaan yang diteliti selama periode pemilihan umum 6 November 2012 di AS. Penelitian selanjutnya dilakukan oleh Yuniarthi dan Sujana (2016) yang mendapatkan hasil bahwa tidak terdapat reaksi pasar terhadap peristiwa pencalonan Jokowi sebagai presiden yang diukur dari abnormal return. Serupa dengan hasil penelitian dari Yuniarthi dan Sujana, Imelda et al., (2015) mendapatkan hasil tes TVA yang tidak menunjukkan perbedaan signifikan sebelum dan sesudah pemilihan presiden di Indonesia tahun 2004, 2009 dan 2014.

Berdasarkan hasil penelitian sebelumnya, diketahui terdapat inkonsistensi dan membuka peluang untuk diteliti kembali. Penelitian ini bertujuan untuk mengetahui reaksi pasar terhadap peristiwa pemilihan presiden tahun 2019 yang difokuskan pada variabel abnormal return dan trading volume activity pada perusahaan yang tercatat di Bursa Efek Indonesia yakni Indeks IDX80. Indeks tersebut dipilih karena memiliki likuiditas yang tinggi, fundamental perusahaan yang baik dan dalam perhitungan indeksnya telah menggunakan metode Capped Free-Float Adjusted Market Capitalization Weighting. 
Menurut Brigham dan Houston (2007:460) informasi adalah sinyal bagi pelaku pasar dalam pengambilan keputusan investasi. Informasi menjadi penting karena informasi pada hakekatnya menyajikan gambaran masa lalu, saat ini maupun keadaan di masa yang akan datang. Apabila informasi memberikan sinyal positif terhadap pasar, maka pasar akan bereaksi yang ditunjukkan dengan adanya perubahan harga dan volume perdagangan saham. Dengan adanya sinyal ini, maka investor akan dapat menentukan sikapnya sebelum dan setelah adanya pengumuman terhadap suatu peristiwa karena setiap tindakan mengandung informasi (Hutami \& Ardiyanto, 2015) yang mana disebabkan oleh informasi yang tidak simetris (Celis \& Shen, 2015).

Pasar dikatakan efisien apabila harga sekuritas bereaksi dengan cepat dan akurat dalam mencapai harga keseimbangan baru yang mencerminkan informasi yang tersedia. Semakin cepat suatu informasi baru yang diberikan terlihat pada harga sekuritasnya, maka dapat dikatakan semakin efisien suatu pasar modal. Konsep pasar efisien menyiratkan adanya suatu proses perubahan harga sekuritas menuju harga keseimbangan baru sebagai respon atas informasi baru yang masuk ke pasar. Harga keseimbangan akan terbentuk setelah investor menilai sepenuhnya dampak dari informasi tersebut (Tandelilin, 2010:219). Menurut Jogiyanto (2016:606) kunci utama dalam mengukur pasar yang efisien adalah hubungan antara harga sekuritas dengan informasi. Fama (1970) mengklasifikasikan bentuk pasar yang efisien ke dalam tiga efficient market hypothesis (EMH) diantaranya weak form, semi-strong form dan strong form. Menurut penelitian yang dilakukan oleh Dwipayana \& Wiksuana (2017), Bursa Efek Indonesia tergolong ke dalam bentuk setengah kuat karena nilai atau harga sekuritasnya secara penuh mencerminkan semua informasi yang dipublikasikan. Konsep efisiensi pasar modal hingga sekarang masih menjadi sebuah perdebatan karena adanya penyimpangan hasil penelitian (Bowes, 2018). Penyimpangan tersebut selanjutnya disebut sebagai anomali pasar (Jones, 2014:331).

Studi peristiwa (event study) merupakan studi yang mempelajari dan mengamati reaksi pasar terhadap suatu peristiwa (event) yang informasinya dipublikasikan sebagai suatu pengumuman. Studi peristiwa dapat digunakan untuk menguji kandungan informasi (information content) dan juga untuk menguji efisiensi pasar bentuk setengah kuat (Jogiyanto, 2016:643). Apabila pasar bereaksi pada waktu informasi tersebut diterima oleh pasar yang ditunjukkan dengan perubahan harga sekuritas, maka dapat dikatakan peristiwa tersebut mengandung informasi yang cukup.

Menurut Jogiyanto (2016:667), abnormal return didapat dari selisih antara return aktual dengan return ekspektasi. Abnormal return berguna untuk melihat seberapa besar pengaruh suatu peristiwa terhadap harga saham (Purwata, 2019). Tiga pendekatan diantaranya mean-adjusted model, market model dan marketadjusted model dapat digunakan untuk mengestimasi return ekspektasi. Apabila peristiwa pemilihan presiden mengandung informasi maka pasar akan bereaksi yang ditunjukkan dengan perubahan abnormal return. Shaikh (2017) menambahkan pada saat pemilihan berlangsung pasar cenderung tidak efisien yang memungkinkan investor untuk mendapatkan abnormal return. 
Penelitian yang terbukti mendukung teori ini diantaranya penelitian yang dilakukan oleh Gatumo (2017) yang mendapatkan hasil pemilihan umum di Kenya memiliki efek positif signifikan pada indeks NSE yang diukur dengan Cumulative Abnormal Return (CAR). Penelitia yang dilakukan oleh Saraswati dan Mustanda (2018) memperoleh hasil terdapat perbedaan abnormal return sebelum dan setelah peristiwa pengumuman hasil penghitungan suara pemilihan umum di AS. Reddy (2018) meneliti pengaruh pemilu di India dan mendapatkan hasil CAR yang positif signifikan terhadap pasar saham. Sajid Nasir et al., (2014) juga menemukan bahwa peristiwa politik berdampak positif signifikan terhadap pasar saham di Pakistan. Kemudian penelitian di Indonesia yang dilakukan oleh Diniar dan Kiryanto (2016) memperoleh hasil yang sama dimana terdapat abnormal return yang signifikan di sekitar peristiwa pemilihan presiden di Indonesia. Berdasarkan hasil penelitian yang telah dilakukan, maka diperoleh hipotesis sebagai berikut.

$\mathrm{H}_{1}$ : Terdapat reaksi pasar yang dilihat dari rata-rata abnormal return saham sebelum dan sesudah peristiwa pemilihan presiden.

Volume perdagangan saham merupakan salah satu indikator yang digunakan untuk melihat reaksi pasar terhadap kejadian atau informasi. Perubahan volume perdagangan diukur melalui trading volume activity. Trading volume activity merupakan perbandingan antara jumlah saham yang diperdagangkan dengan jumlah saham perusahaan yang beredar pada periode tertentu. Pasar akan bereaksi jika suatu peristiwa mengandung informasi yang ditandai dengan perubahan volume perdagangan. Trading volume activity dapat digunakan untuk melihat apakah investor secara individual menilai informasi dari suatu pemilihan presiden sebagai sinyal positif atau negatif untuk membuat keputusan perdagangan saham. Apabila investor mengartikan sebagai sinyal positif suatu informasi, maka permintaan saham akan lebih tinggi daripada penawaran, sehingga volume perdagangan akan meningkat. Sebaliknya, apabila investor mengartikan sebagai sinyal negatif, maka tingkat permintaan saham akan lebih rendah dibandingkan dengan tingkat penawarannya, sehingga volume perdagangan saham cenderung menurun.

Penelitian yang dilakukan oleh Sari dkk., (2017) memperoleh hasil bahwa terdapat perbedaan rata-rata trading volume activity yang signifikan sebelum dan sesudah peristiwa pemilihan presiden AS 2016. Pamungkas dkk., (2015) meneliti pengaruh pemilihan presiden di Indonesia tahun 2014 dengan alat ukur trading volume activity dan memperoleh hasil yaitu terdapat perbedaan rata-rata trading volume activity yang signifikan setelah pemilu presiden di Indonesia. Serupa dengan penelitian sebelumnya, penelitian yang dilakukan oleh Diniar dan Kiryanto (2016) dan Sihotang dan Mekel (2015) memperoleh hasil yakni terdapat perbedaan yang signifikan antara trading volume activity sebelum dan sesudah pemilihan presiden di Indonesia tahun 2014. Berdasarkan hasil penelitian yang telah dilakukan, maka diperoleh hipotesis sebagai berikut.

$\mathrm{H}_{2}$ : Terdapat reaksi pasar yang dilihat dari rata-rata trading volume activity sebelum dan sesudah peristiwa pemilihan presiden. 


\section{METODE PENELITIAN}

Penelitian ini termasuk dalam kategori event study yaitu studi yang mempelajari reaksi pasar terhadap suatu peristiwa yang informasinya dipublikasikan sebagai suatu pengumuman. Lokasi penelitian dilakukan pada perusahaan yang terdaftar di Bursa Efek Indonesia. Peristiwa akan diuji dengan periode jendela yang pendek yakni 11 hari yang bertujuan untuk menghindari bias atas peristiwa yang mungkin terjadi selama periode pengamatan.

Metode pengumpulan data dalam penelitian ini menggunakan metode observasi non partisipan di mana peneliti hanya sebagai pengamat independen dalam mengamati data sekunder (Rahyuda, 2017:153) yang diperoleh dari website www.yahoofinance.com dan www.idx.co.id. Variabel abnormal return dan trading volume activity selanjutnya akan digunakan untuk menguji reaksi pasar terhadap peristiwa pemilihan presiden.

Abnormal return merupakan selisih antara return aktual dengan return ekspektasi. Penelitian ini menggunakan metode market-adjusted model (model disesuaikan-pasar) untuk mengestimasi return ekspektasian. Model ini dianggap sebagai penduga terbaik untuk mengestimasi return suatu sekuritas karena menggunakan return indeks pasar pada saat tersebut. Indeks pasar yang digunakan dalam penelitian ini adalah Indeks IDX80. Langkah-langkah dalam perhitungan abnormal return adalah sebagai berikut.

Actual return dihitung menggunakan rumus berikut.

$\mathrm{R}_{\mathrm{i}, \mathrm{t}}=\left(\mathrm{P}_{\mathrm{i}, \mathrm{t}}-\mathrm{P}_{\mathrm{i}, \mathrm{t}-1}\right) / \mathrm{P}_{\mathrm{i}, \mathrm{t}-1}$

Keterangan:

$\mathrm{R}_{i, t} \quad=$ Return saham pada hari ke- $\mathrm{t}$

$\mathrm{P}_{t} \quad$ = Harga saham penutupan pada hari ke-t

$\mathrm{P}_{t-1} \quad=$ Harga saham penutupan pada hari ke $\mathrm{t}-1$

Expected return dihitung menggunakan rumus berikut

$\mathrm{Rm}, \mathrm{t}=\frac{\text { Il } \quad-\mathrm{II} \quad \mathrm{I}-1}{\text { II }}$ I-I

Keterangan:

$\mathrm{Rm}_{\mathrm{t}} \quad=$ Tingkat return pasar pada saat $\mathrm{t}$

IDX80 ${ }_{\mathrm{t}}=$ Penutupan Indeks IDX80 pada saat $\mathrm{t}$

$\mathrm{IDX} 80_{\mathrm{t}-1}=$ Penutupan Indeks IDX80 pada saat t -1

Abnormal return dihitung menggunakan rumus berikut.

$\mathrm{AR}_{\mathrm{l}, \mathrm{t}}=\mathrm{R}_{\mathrm{l}, \mathrm{t}}-\mathrm{R}_{\mathrm{L}, \mathrm{t}}$

Keterangan:

$\mathrm{AR}_{\mathrm{t}}=$ Abnormal return saham i saat $\mathrm{t}$

$\mathrm{R}_{\mathrm{it}} \quad=$ Return individual saham i saat $\mathrm{t}$

$\mathrm{Rm}_{\mathrm{t}}=$ Tingkat return pasar saham saat $\mathrm{t}$

Rata-rata abnormal return dihitung menggunakan rumus berikut.

$\mathrm{AAR}_{\mathrm{nt}}=\frac{\sum_{\mathrm{t}=1}^{n} \mathrm{ARit}}{\mathrm{n}}$ 
Keterangan:

$\mathrm{AAR}_{\mathrm{nt}}=$ Rata-rata abnormal return saham pada hari $\mathrm{t}$

$\mathrm{n} \quad=$ Sampel

ARit = Abnormal return

Trading volume activity merupakan perbandingan antara jumlah saham yang diperdagangkan dengan jumlah saham perusahaan yang beredar pada periode tertentu. Trading volume activity (TVA) digunakan untuk mengukur besarnya likuiditas sebelum dan sesudah peristiwa pemilihan presiden tahun 2019. Variabel ini akan diamati dengan periode jendela selama 11 hari ( 5 hari sebelum, hari h dan 5 hari sesudah peristiwa). Langkah-langkah dalam perhitungan trading volume activity adalah sebagai berikut.

Trading volume activity dihitung menggunakan rumus berikut.

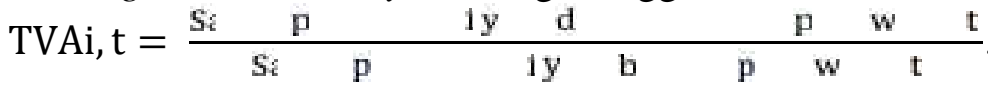

Keterangan:

TVA = Trading volume activity i pada waktu $\mathrm{t}$

i = Nama perusahaan

$\mathrm{t} \quad=$ Waktu tertentu

Rata-rata trading volume activity dihitung menggunakan rumus berikut.

ATVA $=\frac{\sum_{i \cdot 1}^{i k} T V A i}{n}$

Keterangan:

$\mathrm{N}=$ Sampel

TVAi $=$ Trading volume activity

Jumlah sampel dalam penelitian ini yakni sebanyak 63 perusahaan yang diseleksi menggunakan purposive sampling, dengan kriteria pada Tabel 1. berikut.

Tabel 1.

Penentuan Sampel Penelitian

\begin{tabular}{lc}
\hline \multicolumn{1}{c}{ Keterangan } & Jumlah \\
Perusahaan yang tergabung ke dalam Indeks IDX80 & 80 \\
Perusahaan terindikasi confounding effect & $(17)$ \\
Perusahaan sedang disuspend selama pengamatan & $(0)$ \\
Perusahaan yang memenuhi kriteria & $\mathbf{6 3}$ \\
\hline
\end{tabular}

Sumber: www.idx.co.id, 2019

Untuk memecahkan pemasalahan terkait ada tidaknya reaksi pasar yang dilihat dari rata-rata abnormal return dan rata-rata trading volume activity, maka teknik analisis data menggunakan metode uji beda. Uji beda dilakukan untuk mengetahui apakah pasar bereaksi terhadap peristiwa pemilihan presiden dengan menghitung rata-rata abnormal return dan rata-rata trading volume activity. Langkah awal dalam menentukan uji hipotesis (statistik parametrik atau non parametrik) yang akan digunakan adalah dengan seleksi uji normalitas.

Uji normalitas digunakan untuk menguji penyebaran data. Data berdistribusi normal apabila Asymp. Sig (2-tailed) > a. Uji statistik parametrik yakni Paired 
Sample T-test dapat digunakan jika data berdistribusi normal. Apabila data berdistribusi tidak normal, maka dapat menggunakan uji statistik non parametrik yakni Wilcoxon Signed Rank Test. Kriteria pengambilan keputusan; $\mathrm{H}_{0}$ diterima apabila probabilitas (Asymp. Sig) $\geq \mathrm{t}\left(\right.$ alpha) dan $\mathrm{H}_{1}$ ditolak bila (Asymp. Sig) $\geq \mathrm{t}$ (alpha).

\section{HASIL DAN PEMBAHASAN}

Indeks IDX80 berisi 80 saham perusahaan terdaftar yang memiliki fundamental baik, likuiditas tinggi, dan kapitalisasi pasar besar. Metode perhitungan Indeks yakni Capped Free-Float Adjusted Market Capitalization Weighting yang mana memperhatikan kapitalisasi pasar free float merupakan ciri khas dari Indeks ini. Jumlah sampel dari penelitian ini terdiri dari 63 perusahaan yang diseleksi menggunakan purposive sampling dengan kriteria; tergabung dalam Indeks IDX80, bebas dari confounding effect dan tidak sedang disuspend selama periode pengamatan. Dari 63 sampel tersebut, digolongkan berdasarkan sektornya sebagai berikut.

Tabel 2.

Perusahaan Sampel Berdasarkan Sektornya

\begin{tabular}{clcc}
\hline No & \multicolumn{1}{c}{ Sektor Industri Perusahaan } & Jumlah & Persentase (\%) \\
\hline 1 & Agriculture & 2 & 3 \\
2 & Mining & 6 & 10 \\
3 & Basic Industry and Chemicals & 8 & 13 \\
4 & Miscellaneous Industry & 3 & 5 \\
5 & Consumer Goods Industry & 9 & 14 \\
6 & Property, Real Estate and Building Construction & 12 & 19 \\
7 & Infrastructure, Utilities and Transportation & 5 & 8 \\
8 & Finance & 8 & 13 \\
9 & Trade, Service and Invesment & 10 & 16 \\
\multicolumn{2}{r}{ Total } & $\mathbf{6 3}$ & $\mathbf{1 0 0}$ \\
\hline
\end{tabular}

Sumber: www.idx.co.id, 2019

Tabel 3. dan Gambar 2. menunjukkan hasil perhitungan rata-rata abnormal return sekitar peristiwa selama 11 hari yang diperoleh dari data harga saham penutupan harian dan data penutupan harian Indeks IDX80 untuk perusahaanperusahaan yang dijadikan sampel selama event period.

Tabel 3. dan Gambar 2. memperlihatkan berfluktuasinya nilai rata-rata abnormal return selama 11 hari periode peristiwa. Pada periode sebelum peristiwa pemilihan, pergerakan rata-rata abnormal return terlihat menurun yang dimulai pada periode $\mathrm{H}-4$ dan mencapai titik terendah yakni sebesar $-0,0035$ pada periode H-1. Sehari setelah pemilihan presiden tahun 2019, pergerakan rata-rata abnormal return langsung meningkat menjadi $-0,0006$. Hal tersebut menggambarkan bahwa ketidakpastian dari peristiwa politik mulai berkurang yang direduksi oleh hasil perhitungan quick count sementara tanggal 18 April 2019. Nilai rata-rata abnormal return tertinggi sesudah peristiwa pemilihan terjadi pada periode $\mathrm{H}+3$ yakni sebesar 0,00458 dan kembali menurun pada periode $\mathrm{H}+4$ dan $\mathrm{H}+5$. 
Tabel 3.

Rata-Rata Abnormal Return Sekitar Peristiwa

\begin{tabular}{ccc}
\hline Tanggal & Periode & AAR \\
\hline Rabu, 10 April 2019 & $\mathrm{H}-5$ & $-0,00252$ \\
Kamis, 11 April 2019 & $\mathrm{H}-4$ & 0,00673 \\
Jumat, 12 April 2019 & $\mathrm{H}-3$ & $-0,00024$ \\
Senin, 15 April 2019 & $\mathrm{H}-2$ & $-0,00059$ \\
Selasa, 16 April 2019 & $\mathrm{H}-1$ & $-0,00352$ \\
Rabu, 17 April 2019 & $\mathrm{H}$ & 0 \\
Kamis, 18 April 2019 & $\mathrm{H}+1$ & $-0,00064$ \\
Senin, 22 April 2019 & $\mathrm{H}+2$ & $-0,00072$ \\
Selasa, 23 April 2019 & $\mathrm{H}+3$ & 0,00458 \\
Rabu, 24 April 2019 & $\mathrm{H}+4$ & 0,00265 \\
Kamis, 25 April 2019 & $\mathrm{H}+5$ & $-0,00058$ \\
\hline
\end{tabular}

Sumber: Data sekunder diolah, 2019

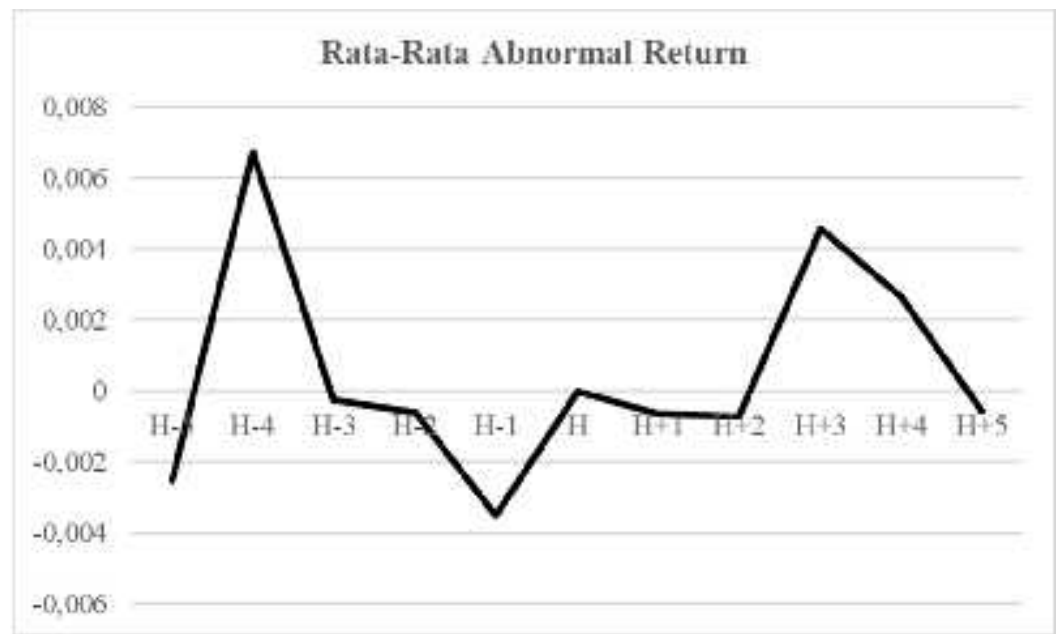

Gambar 2. Pergerakan Rata-Rata Abnormal Return

Sumber: Data sekunder diolah, 2019

Tabel 4.

Rata-Rata Trading Volume Activity Sekitar Peristiwa

\begin{tabular}{ccc} 
Tanggal & Periode & ATVA \\
\hline Rabu, 10 April 2019 & $\mathrm{H}-5$ & 0,00151 \\
Kamis, 11 April 2019 & $\mathrm{H}-4$ & 0,00131 \\
Jumat, 12 April 2019 & $\mathrm{H}-3$ & 0,00104 \\
Senin, 15 April 2019 & $\mathrm{H}-2$ & 0,00181 \\
Selasa, 16 April 2019 & $\mathrm{H}-1$ & 0,00213 \\
Rabu, 17 April 2019 & $\mathrm{H}$ & 0 \\
Kamis, 18 April 2019 & $\mathrm{H}+1$ & 0,00342 \\
Senin, 22 April 2019 & $\mathrm{H}+2$ & 0,00169 \\
Selasa, 23 April 2019 & $\mathrm{H}+3$ & 0,00204 \\
Rabu, 24 April 2019 & $\mathrm{H}+4$ & 0,00196 \\
Kamis, 25 April 2019 & $\mathrm{H}+5$ & 0,00189
\end{tabular}

Sumber: Data sekunder diolah, 2019 


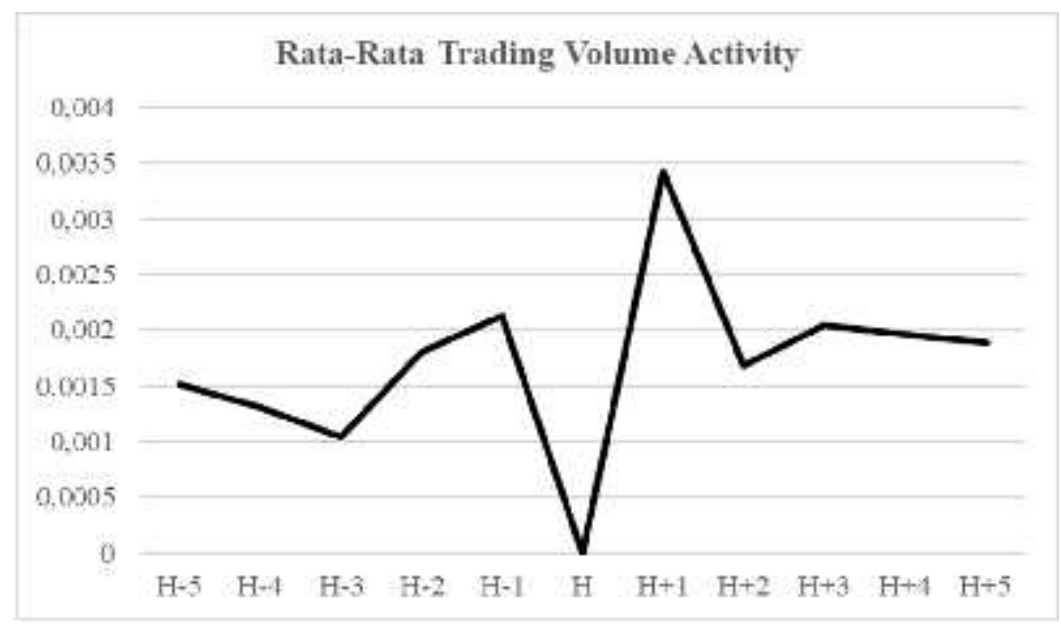

Gambar 3. Pergerakan Rata-Rata Trading Volume Activity

Sumber: Data sekunder diolah, 2019

Tabel 4. dan Gambar 3. menunjukkan volatilitas rata-rata trading volume activity selama 11 hari periode peristiwa. Pada periode sebelum peristiwa pemilihan presiden tahun 2019, rata-rata trading volume activity mengalami peningkatan yang dimulai dari periode $\mathrm{H}-3$. Puncak kenaikan rata-rata trading volume activity terjadi pada periode $\mathrm{H}+1$ yakni sebesar 0,0034 yang menggambarkan volatilitas yang sangat tinggi dimana para spekulan berspekulasi untuk mendapatkan abnormal return di sekitar peristiwa pemilihan sehingga volume perdagangan meningkat. Namun, pada periode $\mathrm{H}+2$ atau sehari setelah periode $\mathrm{H}+1$, trading volume activity mengalami penurunan sebesar 0,0017 dan mengalami sideways hingga periode $\mathrm{H}+5$.

Tabel 5.

Deskripsi Data Rata-Rata Abnormal Return

\begin{tabular}{llcccc}
\hline & N & Minimum & Maximum & Mean & Std. Deviation \\
\hline AAR_Sebelum & 63 & $-0,0185324$ & 0,0211746 & $-0,000028328$ & 0,0082702162 \\
AAR_Sesudah & 63 & $-0,0250495$ & 0,0238440 & 0,000883389 & 0,0088949266
\end{tabular}

Valid N

63

(listwise)

Sumber: Data sekunder diolah, 2019

Nilai terendah rata-rata abnormal return sebelum peristiwa pemilihan presiden tahun 2019 didapatkan oleh perusahaan Erajaya Swasembada Tbk. sebesar -0,0185324 sedangkan nilai tertinggi didapatkan oleh perusahaan Bank Tabungan Negara (Persero) Tbk. sebesar 0,0211746. Secara statistik rata-rata abnormal return perusahaan pada lima hari sebelum peristiwa pemilihan presiden tahun 2019 mempunyai rata-rata sebesar -0,000028328 dengan rata-rata penyimpangan abnormal return sebesar 0,0082702162. Hal ini menggambarkan bahwa terdapat rata-rata abnormal return negatif yang berarti bahwa return aktual yang terjadi lebih rendah daripada return yang diharapkan. 
Nilai terendah rata-rata abnormal return sesudah peristiwa pemilihan presiden tahun 2019 diperoleh oleh perusahaan Charoen Pokphand Indonesia Tbk. sebesar -0,0250495 sedangkan nilai tertinggi diperoleh oleh perusahaan Surya Semesta Internusa Tbk. sebesar 0,0238440. Secara statistik, rata-rata abnormal return perusahaan lima hari sesudah peristiwa pemilihan presiden tahun 2019 memiliki rata-rata sebesar 0,000883389 dengan rata-rata penyimpangan abnormal return sebesar 0,0088949266. Hal ini menunjukkan terdapat rata-rata abnormal return positif yang berarti bahwa abnormal return aktual yang terjadi lebih tinggi daripada abnormal return yang diharapkan.

Tabel 6.

Deskripsi Data Rata-Rata Trading Volume Activity

\begin{tabular}{llllcl}
\hline & N & Minimum & Maximum & Mean & Std. Deviation \\
\hline ATVA_Sebelum & 63 & 0,0000330 & 0,0093915 & 0,001560338 & 0,0020486824 \\
ATVA_Sesudah & 63 & 0,0000213 & 0,0122573 & 0,001835257 & 0,0022805796 \\
Valid N (listwise) & 63 & & & & \\
\hline
\end{tabular}

Sumber: Data sekunder diolah, 2019

Nilai terendah rata-rata trading volume activity sebelum peristiwa pemilihan presiden tahun 2019 diperoleh oleh perusahaan Bank Danamon Indonesia Tbk. sebesar 0,0000330 sedangkan nilai tertinggi diperoleh oleh perusahaan Erajaya Swasembada Tbk. sebesar 0,0093915. Secara statistik rata-rata trading volume activity perusahaan pada lima hari sebelum peristiwa pemilihan presiden tahun 2019 memiliki rata-rata sebesar 0,001560338 dengan rata-rata penyimpangan sebesar 0,0020486824. Hal ini menunjukkan terdapat rata-rata trading volume activity positif sebelum peristiwa pemilihan presiden tahun 2019.

Nilai terendah rata-rata trading volume activity sesudah peristiwa pemilihan presiden tahun 2019 diperoleh oleh perusahaan Mayora Indah Tbk. sebesar 0,0000213 sedangkan nilai tertinggi diperoleh oleh perusahaan Erajaya Swasembada Tbk. sebesar 0,0122573. Secara statistik rata-rata trading volume activity perusahaan pada lima hari sesudah peristiwa pemilihan presiden tahun 2019 memiliki rata-rata sebesar 0,001835257 dengan rata-rata penyimpangan sebesar 0,0022805796. Hal ini menunjukkan terdapat rata-rata trading volume activity positif sesudah peristiwa pemilihan presiden tahun 2019. Secara statistik, nilai mean dari rata-rata trading volume activity sesudah peristiwa lebih besar dari pada nilai mean rata-rata trading volume activity sebelum peristiwa pemilihan presiden tahun 2019. Hal ini menggambarkan bahwa terjadi peningkatan volume perdagangan setelah peristiwa pemilihan.

Tabel 7. menampilkan hasil uji normalitas rata-rata abnormal return sebelum dan sesudah dari 63 perusahaan. Hasil pengujian menunjukkan nilai Sig. (2-tailed) sebelum peristiwa pemilihan presiden tahun 2019 sebesar 0,097 > alpha dan nilai Sig. (2-tailed) sesudah peristiwa pemilihan presiden tahun 2019 sebesar 0,006 < alpha. Dari kedua hasil pengujian, dimana nilai Sig. (2-tailed) sebelum dan sesudah peristiwa pemilihan presiden tahun 2019 diketahui terjadi inkonsistensi yang artinya data rata-rata abnormal return tidak berdistribusi normal dan selanjutnya untuk pengujian hipotesis penelitian dapat menggunakan metode analisis non parametrik yakni Wilcoxon Signed Ranks Test. 
Tabel 7.

Hasil Uji Normalitas Rata-Rata Abnormal Return

\begin{tabular}{llrr}
\hline & & AAR Sebelum & \multicolumn{1}{c}{ AAR Sesudah } \\
\hline $\mathrm{N}$ & & 63 & 63 \\
Normal Parameters & Mean & $-0,000028328$ & 0,000883389 \\
& Std. Deviation & 0,0082702162 & 0,0088949266 \\
Most Extreme Differences & Absolute & 0,103 & 0,135 \\
& Positive & 0,103 & 0,134 \\
& Negative & $-0,065$ & $-0,135$ \\
& & 0,103 & 0,135 \\
Kolmogorov-Smirnov Z & & 0,097 & 0,006 \\
Asymp. Sig. (2-tailed) & & &
\end{tabular}

Tabel 8.

Hasil Uji Normalitas Rata-Rata Trading Volume Activity

\begin{tabular}{|c|c|c|c|}
\hline & & ATVA Sebelum & Sesudah \\
\hline $\mathrm{N}$ & & 63 & 63 \\
\hline \multirow{2}{*}{ Normal Parameters ${ }^{\mathrm{a}, \mathrm{b}}$} & Mean & 0,001560338 & 0,001835257 \\
\hline & Std. Deviation & 0,0020486824 & 0,0022805796 \\
\hline \multirow[t]{3}{*}{ Most Extreme Differences } & Absolute & 0,289 & 0,264 \\
\hline & Positive & 0,289 & 0,264 \\
\hline & Negative & $-0,228$ & $-0,213$ \\
\hline gorov-Smirnov Z & & 0,289 & 0,264 \\
\hline Asymp. Sig. (2-tailed) & & 0,000 & 0,000 \\
\hline
\end{tabular}

Sumber: Data sekunder diolah, 2019

Tabel 8. menampilkan hasil uji normalitas rata-rata trading volume activity sebelum dan sesudah dari 63 perusahaan. Hasil pengujian menunjukkan nilai Sig. (2-tailed) sebelum peristiwa pemilihan presiden tahun 2019 sebesar $0,000<$ alpha dan nilai Sig. (2-tailed) sesudah peristiwa pemilihan presiden tahun 2019 sebesar $0,000<$ alpha. Dari kedua hasil pengujian, dimana nilai Sig. (2-tailed) sebelum dan sesudah peristiwa pemilihan presiden tahun 2019 sama-sama < alpha yang artinya data rata-rata trading volume activity tidak berdistribusi normal dan selanjutnya untuk pengujian hipotesis penelitian dapat menggunakan metode analisis non parametrik yakni Wilcoxon Signed Ranks Test.

Hasil uji hipotesis perbedaan rata-rata abnormal return sebelum dan sesudah peristiwa pemilihan presiden tahun 2019 dapat diketahui pada Tabel 9. berikut.

Tabel 9.

Hasil Uji Hipotesis Rata-Rata Abnormal Return

\begin{tabular}{lr}
\hline & AAR Sebelum - AAR Sesudah \\
\hline Z & $-0,342$ \\
Asymp. Sig. (2-tailed) & 0,732 \\
\hline Sumber: Data diolah, 2019
\end{tabular}

Tabel 9. menunjukkan nilai Sig. (2-tailed) rata-rata abnormal return sebelum dan sesudah peristiwa pemilihan yakni sebesar 0,732. Oleh karena Sig. (2-tailed) variabel rata-rata abnormal return sebesar 0,732 >0,05 (alpha), maka dapat disimpulkan bahwa $\mathrm{H}_{1}$ ditolak dan $\mathrm{H}_{0}$ diterima. Hal ini juga membuktikan 
bahwa tidak terdapat perbedaan rata-rata abnormal return yang signifikan sebelum dan sesudah peristiwa pemilihan presiden tahun 2019 dengan event window selama 11 hari.

Hasil uji hipotesis perbedaan rata-rata trading volume activity sebelum dan sesudah peristiwa pemilihan presiden tahun 2019 dapat diketahui pada Tabel 10 . berikut.

Tabel 10.

Hasil Uji Hipotesis Rata-Rata Trading Volume Activity

\begin{tabular}{lr}
\hline & ATVA Sebelum - ATVA Sesudah \\
\hline$Z$ & $-3,690$ \\
Asymp. Sig. (2-tailed) & 0,000 \\
\hline a. Wilcoxon Signed Ranks Test & \\
b. Based on positive ranks. & \\
Sumber: Data sekunder diolah, 2019 &
\end{tabular}

Tabel 10. menunjukkan nilai Sig. (2-tailed) rata-rata trading volume activity sebelum dan sesudah peristiwa pemilihan presiden yakni sebesar 0,000. Oleh karena Sig. (2-tailed) variabel rata-rata trading volume activity sebesar 0,000 < 0,05 (alpha), maka dapat disimpulkan bahwa $\mathrm{H}_{2}$ diterima dan $\mathrm{H}_{0}$ ditolak. Hal ini juga membuktikan bahwa terdapat perbedaan rata-rata trading volume activity yang signifikan sebelum dan sesudah peristiwa pemilihan presiden tahun 2019 dengan event window selama 11 hari.

Hasil pengujian terhadap Hipotesis $1\left(\mathrm{H}_{1}\right)$ yang menyatakan terdapat reaksi pasar yang dilihat dari rata-rata abnormal return saham sebelum dan sesudah peristiwa pemilihan presiden tahun 2019, mendapatkan nilai signifikansi sebesar 0,732 > 0,05 (alpha) yang mana menolak $\mathrm{H}_{1}$ dan menerima $\mathrm{H}_{0}$. Peristiwa pemilihan presiden tahun 2019 cukup membuat pasar bereaksi yang dibuktikan dengan adanya perubahan nilai rata-rata abnormal return sebelum (negatif sebesar -0,000028328) dan sesudah peristiwa pemilihan (positif sebesar 0,000883389). Terjadinya perubahan nilai rata-rata abnormal return merupakan indikasi bahwa investor merespon informasi dari suatu peristiwa. Sesuai dengan teori efisiensi pasar yang ditinjau dari sudut informasi, yang mana pasar modal Indonesia termasuk efisien dalam bentuk setengah kuat (semi-strong form) karena terjadi respon atas peristiwa yang informasinya dipublikasikan dalam bentuk perubahan rata-rata abnormal return sebelum dan sesudah peristiwa.

Meskipun peristiwa pemilihan presiden tahun 2019 menyebabkan perubahan rata-rata abnormal return, namun pengaruh tersebut tidak signifikan. Pengaruh yang tidak signifikan menunjukkan bahwa informasi yang terkandung dalam suatu peristiwa tidak cukup kuat sehingga secara signifikan tidak terlihat perbedaan rata-ratanya terhadap abnormal return atau dengan kata lain pasar tidak bereaksi. Hal ini dimungkinkan karena pasar telah mengantisipasi terlebih dahulu informasi yang terkandung dalam peristiwa tersebut sehingga pelaku pasar berspekulasi atau melakukan transaksi jual-beli dalam waktu singkat.

Hasil penelitian yang berbeda didapatkan oleh Diniar dan Kiryanto (2016) yang memperoleh hasil dimana terdapat abnormal return yang signifikan di 
sekitar peristiwa pemilihan presiden di Indonesia tahun 2014. Hasil penelitian dari Osuala et al., (2018) yang meneliti reaksi pasar terhadap pemilihan presiden di Nigeria mendapatkan hasil negatif signifikan. Namun, hasil penelitian ini sama dengan yang dilakukan oleh Sari dkk. (2017) yang meneliti perbedaan rata-rata abnormal return dan trading volume activity sebelum dan sesudah pilpres Amerika Serikat 2016 dan mendapatkan hasil tidak terdapat perbedaan rata-rata abnormal return yang signifikan sebelum dan sesudah peristiwa pilpres Amerika Serikat 2016.

Hasil pengujian terhadap Hipotesis $2\left(\mathrm{H}_{2}\right)$ yang menyatakan terdapat reaksi pasar yang dilihat dari rata-rata trading volume activity saham sebelum dan sesudah peristiwa pemilihan presiden tahun 2019, mendapatkan nilai signifikansi $0,000<0,05$ (alpha) yang mana menerima $\mathrm{H}_{2}$ dan menolak $\mathrm{H}_{0}$. Perbedaan trading volume activity pada penelitian ini terjadi karena peningkatan rata-rata trading volume activity sesudah peristiwa pemilihan yakni sebesar 0,001835257. Sesuai dengan teori efisiensi pasar yang ditinjau dari sudut informasi yang mana pasar efisien dalam bentuk setengah kuat (semi-strong form) terjadi jika pasar merespon informasi atas peristiwa yang dipublikasikan. Respon pasar dalam penelitian ini direpresentasikan dalam bentuk perubahan rata-rata trading volume activity sebelum dan sesudah peristiwa yang signifikan atau dengan kata lain pasar bereaksi.

Peningkatan rata-rata trading volume activity sesudah peristiwa pemilihan disebabkan karena kandungan informasi dalam peristiwa tersebut dinilai baik (good news) oleh investor. Alasan investor menilai informasi ini sebagai good news karena berselang beberapa jam setelah pemungutan suara tanggal 17 April 2019 selesai, beberapa lembaga seperti Litbang Kompas, Indo Barometer dan LSI Denny JA mempublikasikan hasil quick count yang menyatakan 55 persen suara untuk Jokowi-Ma'ruf dan 45 persen suara untuk Prabowo-Sandi, sehingga dapat mereduksi ketidakpastian dari peristiwa politik. Sekalipun rata-rata trading volume activity meningkat yang menandakan keinginan investor untuk membeli atau menjual saham sesuai harga dan jumlah yang diinginkan, namun tidaklah selalu memperoleh keuntungan sesuai yang diharapkan (Sihotang \& Mekel, 2015).

Hasil penelitian yang sama juga didapatkan oleh Sari dkk. (2017) yang memperoleh hasil bahwa terdapat perbedaan rata-rata trading volume activity yang signifikan sebelum dan sesudah peristiwa pemilihan presiden di AS tahun 2016. Pamungkas dkk. (2015) meneliti pengaruh pemilihan presiden di Indonesia tahun 2014 dan memperoleh hasil yakni terdapat perbedaan rata-rata trading volume activity yang signifikan setelah pemilu presiden di Indonesia. Kemudian penelitian dari Sihotang dan Mekel (2015) memperoleh hasil yakni terdapat perbedaan yang signifikan antara trading volume activity sebelum dan sesudah pemilihan presiden di Indonesia tahun 2014.

\section{SIMPULAN}

Berdasarkan hasil pengujian, kesimpulan yang diperoleh adalah tidak terdapat reaksi pasar yang ditunjukkan dengan nilai signifikansi rata-rata abnormal return sebelum dan sesudah peristiwa pemilihan yang tidak signifikan 
dan terdapat reaksi pasar yang ditunjukkan dengan nilai signifikansi rata-rata trading volume activity sebelum dan sesudah peristiwa pemilihan yang signifikan.

Berdasarkan hasil penelitian, maka saran yang dapat diajukan kepada investor yakni sebaiknya berhati-hati dalam berinvestasi pada hari dekat peristiwa pemilihan karena volatilitas yang tinggi. Selain itu, sebaiknya investor menganalisis terlebih dahulu apakah suatu informasi mengandung good news atau bad news yang akan memengaruhi reaksi pasar. Saran bagi peneliti selanjutnya diharapkan dapat menyempurnakan penelitian ini yakni dengan menggunakan pendekatan sampel jenuh atau semua perusahaan yang terdaftar di BEI dan menggunakan pendekatan lain dalam menentukan return ekspektasi seperti market model dan mead adjusted model.

\section{REFERENSI}

Altin, Hakan. (2015). Efficient Market Hypothesis, Abnormal Return and Election Periods. European Scientific Journal, 11(34), 169-178.

Bowes, David. R. (2018). Stock Market Volatility and Presidential Election Uncertainty: Evidence from Political Futures Markets. Journal of Applied Business Research, 34(1), 143-150.

Brigham, E. F., \& Houston, J. F. (2007). Fundamentals of Financial Management (Eleventh Edition). Engineering and Process Economics.

Budiman, Agus. (2015). Analisis Perbandingan Average Abnormal Return dan Average Trading Volume Activity Sebelum dan Sesudah Peristiwa Pemilihan Umum Presiden dan Wakil Presiden Tahun 2009 dan 2014 (Studi Pada Saham-Saham LQ-45 di Bursa Efek Indonesia). Skripsi: Universitas Negeri Semarang.

Bursa Efek Indonesia. (2019). http://www.idx.co.id/Diakses 3 Mei 2019.

Celis, Evelita E., \& Shen, Leow J. (2015). Political Cycle and Stock Market - The Case of Malaysia. Journal of Emerging Issues in Economics, Finance and Banking, 4(1), 1461-1512.

Chien, Wen-W., Mayer, Roger W., \& Wang, Z. (2014). Stock Market, Economic Performance, And Presidential Elections. Journal of Business and Economics Research, 12(2), 159-170.

Diniar, A. H., \& Kiryanto, K. (2016). Analisis Dampak Pemilu Presiden Jokowi Terhadap Return Saham. Jurnal Akuntansi Indonesia, 4(2), 97-108.

Dwipayana, I Gst. Ngr. A. P., \& Wiksuana, I Gst. Bgs. (2017). Pengujian Efisiensi Pasar Di Bursa Efek Indonesia. E-Jurnal Manajemen Unud, 6(4), 2105-2132. 
Fama, Eugene F. (1970). Efficient Capital Markets: A Review Of Theory and Empirical Work. The Journal of Finance, 25(2), 383-417.

Gatumo, F. Mambo. (2017). General Elections and Stock Markets: Did August 2017 General Election In Kenya Influence The Stock Market? IOSR Journal of Business and Management, 19(11), 56-59.

Hoe, S., \& Nippani, S. (2017). 2016 U.S. Presidential Election and Stock Markets in China. International Journal of Economics and Finance, 9(7), 32-38.

Husnan, S. (2003). Dasar-Dasar Teori Portofolio dan Analisis Sekuritas (Edisi Ketiga). AMP YKPN: Yogyakarta.

Hutami, R. N., \& Ardiyanto, M. D. (2015). Abnormal Return dan Trading Volume Activity Sebelum dan Setelah Pemilihan Presiden Secara Langsung 9 Juli 2014 (Studi Kasus Pada Saham LQ-45). Diponegoro Journal of Accounting, 4(2), 1-10.

Imelda, Siregar, H., \& Anggraeni, L. (2015). Abnormal Returns and Trading Volume in the Indonesian Stock Market in Relation to the Presidential Elections in 2004, 2009, and 2014. International Journal of Administrative Science and Organization, 21(2), 66-76.

Isa, M. (2018). Mengenal Perbedaan UU Pemilu 2019 dengan UU Pemilu Sebelumnya: http://www.radarbangsa.com/opini/l6532/mengenalperbedaan-uu-pemilu-2019-dengan-uu-pemilu-sebelumnya. Diakses tanggal 4 April 2019.

Jiun, Ricky C. C. (2018). The Effect of Political Elections on Stock Market Volatility in Malaysia. International Journal of Engineering and Technology, 7, 114-119.

Jogiyanto, Hartono. (2016). Teori Portofolio dan Analisis Investasi (Edisi Kesebelas). BPPE: Yogyakarta.

Jones, Charles P. (2012). Investment Analysis and Management (Twelfth Edition). US of America: MPS Limited.

Kabiru, J. N., Ochieng, D. E., \& Kinyua, H. W. (2015). The Effect of General Elections on Stock Returns at The Nairobi Securities Exchange. European Scientific Journal, 11(28), 435-460.

Katti, Siti Wardani Bakri. (2018). Pengaruh Peristiwa Politik (Pemilu Presiden dan Pengumuman Susunan Kabinet) Terhadap Saham Sektor Industri Di Bursa Efek Indonesia. Jurnal Capital, 1(2), 126-134. 
Khan, S., Jafri, R. A., Baig, N., Shaique, M., \& Usman, M. (2017). Stock Index Manipulation Around Election Announcements: Evidence from Pakistan Stock Exchange. International Journal of Accounting and Economics Studies, 5(2), 87-91.

Khim-Sen Liew, V., \& Rowland, R. (2016). The Effect of Malaysia General Election on Stock Market Returns. SpringerPlus, 5, 1-13.

Koulakiotis, A., Papapanagos, H., \& Papasyriopoulos, N. (2016). Political Elections, Abnormal Returns and Stock Price Volatility: The Case of Greece. Investment Management and Financial Innovations, 13(1), 161169.

Kurniawati, A., \& Herlambang, L. (2015). Reaksi Pasar Atas Hasil Pemilu Presiden 2014 (Studi Pada Emiten yang Listing di Jakarta Islamic Index). Jurnal Ekonomi Syariah Teori Dan Terapan, 2(3), 233-247.

Kusumayanti, K. R., \& Suarjaya, A. A. G. (2018). Reaksi Pasar Modal Terhadap Pengumuman Kemenangan Donald Trump Dalam Pilpres Amerika Serikat 2016. E-Jurnal Manajemen Unud, 7(4), 1713-1741.

Mahaputra, I Made Dwi \& Purbawangsa, Ida Bagus Anom. (2015). Pengaruh Peristiwa Pemilu Legislatif 2014 Terhadap Perolehan Abnormal Return Saham LQ45 Di Bursa Efek Indonesia. E-Jurnal Manajemen Unud, 4(5), 1406-1421.

Obradovic, S. \& Tomic, N. (2017). The Effect of Presidential Election in The USA on Stock Return Flow: A Study of A Political Event. Economic Research, 30(1), 112-124.

Oka Sudewa P, D. G., dan Ratna Sari, M. M. (2015). Reaksi Pasar Atas Peristiwa Pilpres 2014. E-Jurnal Akuntansi Unud, 12(3), 465-480.

Osuala, A. E., Onoh, U. A., \& Nwansi, G. U. (2018). Presidential Election Results and Stock Market Performance: Evidence from Nigeria. Journal of Applied Economics and Finance, 5(2), 117-124.

Pamungkas, A., Suhadak, \& Endang. (2015). Pengaruh Pemilu Presiden Indonesia Tahun 2014 terhadap Abnormal Return dan Trading Volume Activity (Studi pada Perusahaan yang Tercatat sebagai Anggota Indeks Kompas 100). Jurnal Administrasi Bisnis (JAB), 20(1), 1-9.

Purwata, I Putu dan Wiksuana, I. G. B. (2019). Reaksi Pasar Terhadap Peristiwa Stock Split Di Bursa Efek Indonesia. E-Jurnal Manajemen Unud, 8(4), 2352-2380. 
Rahyuda, Ketut. (2017). Metode Penelitian Bisnis (Edisi Revisi 2017). Denpasar: Udayana University Press.

Reddy, G. Sudarsana. (2018). Impact of General Elections 2014 on Indian Stock Market with Special References to the Stock of Select Companies in BSE. International Journal of Management Studies, 5(3), 123-132.

Sajid Nasir, M., Younus, H., Kaleem, A., \& Anwar, Z. (2014). Impact of Political Events on Stock Market Returns: Empirical Evidence from Pakistan. Journal of Economic and Administrative, 30(1), 60-78.

Santoso, H., \& Sri Artini, L. G. (2015). Reaksi Pasar Modal Indonesia Terhadap Pemilu Legislatif 2014 Pada Indeks LQ45 di BEI. E-Jurnal Manajemen Unud, 4(9), 2647-2674.

Saraswati, N. M. A. W., \& Mustanda, I. K. (2018). Reaksi Pasar Modal Indonesia Terhadap Peristiwa Pengumuman Hasil Penghitungan Suara Pemilihan Umum Dan Pelantikan Presiden Amerika Serikat. E-Jurnal Manajemen Unud, 7(6), 2971-2998.

Sari, N. P. T. P., Purnamawati, I. G. A. \& Herawati, N. T. (2017). Analisis Komparatif Saham LQ-45 Sebelum dan Sesudah Pilpres Amerika Serikat 2016. E-Journal S1 Ak Universitas Pendidikan Ganesha, 7(1), 1-10.

Savita \& Ramesh, A. (2015). Return Volatility Around National Elections: Evidence from India. Journal Social and Behavioral Sciences 189, 163-168.

Shaikh, Imlak. (2017). The 2016 U.S. Presidential Election and The Stock, FX and VIX Markets. North American Journal of Economics and Finance, 42, 546-563.

Sihotang, Eva Maria \& Mekel, Peggy Adeline. (2015). Reaksi Pasar Modal Terhadap Pemilihan Umum Presiden Tanggal 9 Juli 2014 di Indonesia (Studi di Perusahaan Konstruksi, Infrastruktur dan Utilitas Pada BEI, Jakarta). Jurnal Riset Ekonomi, Manajemen, Bisnis Dan Akuntansi, 3(1), 951-960.

Tandelilin, Eduardus. (2010). Portofolio dan Investasi: Teori dan Aplikasi (Edisi Pertama). Kanisius: Yogyakarta.

Undang-Undang No. 7 Tahun 2017. (2019). http://indonesia-oslo.no/Diakses 18 April 2019.

Wong, Wai-Yan \& Hooy, Chee-Wooi. (2016). The Impact of Election on Stock Market Returns of Government-Owned Banks: The Case of Indonesia, Malaysia and Thailand. Asian Journal of Business and Accounting, 9(1), 3158 . 
Putu Agus Yudiawan, Reaksi Pasar Terhadap...

Yahoo Finance. (2019). https://finance.yahoo.com/ Diakses 28 April 2019.

Yuniarthi, Ni Nengah Sureni \& Sujana, I Ketut. (2016). Reaksi Pasar Modal Terhadap Pencalonan Jokowi Menjadi Presiden Republik Indonesia. EJurnal Akuntansi Unud, 16(2), 951-977. 